\title{
Tipping Point for Expansion of Layered Aluminosilicates in Weakly Polar Solvents: Supercritical CO2
}

\author{
Herbert T. Schaef ${ }^{*}$, Narasimhan Loganathan ${ }^{2}$, Geoffrey M. Bowers ${ }^{3}$, R. James Kirkpatrick ${ }^{2}$, A. Ozgur \\ Yazaydin $^{2,4}$, Sarah D. Burton ${ }^{5}$, David W. Hoyt ${ }^{5}$, K. Sahan Thanthiriwatte ${ }^{6}$, David A. Dixon ${ }^{6}$, B. Peter \\ McGrail $^{1}$, Kevin M. Rosso ${ }^{1}$, Eugene S. Ilton ${ }^{1}$, John S. Loring ${ }^{1 *}$ \\ ${ }^{1}$ Pacific Northwest National Laboratory, Richland WA 99356 \\ ${ }^{2}$ College of Natural Science, Michigan State University, East Lansing, MI, 48824 \\ ${ }^{3}$ Department of Chemistry and Biochemistry, St. Mary's College of Maryland, St. Mary's City, MD 20686 \\ ${ }^{4}$ Department of Chemical Engineering, University College London, London, WC1E 7JE, United Kingdom \\ ${ }^{5}$ William R. Wiley Environmental and Molecular Sciences Laboratory, Pacific Northwest National Laboratory, Richland, \\ WA, 99356 \\ ${ }^{6}$ Department of Chemistry, The University of Alabama, Tuscaloosa, AL 35487
}

KEYWORDS: carbon dioxide; montmorillonite; intercalation: Molecular dynamics; interlayer expansion.

\begin{abstract}
Layered aluminosilicates play a dominant role in the mechanical and gas storage properties of the subsurface, are used in diverse industrial applications, and serve as model materials for understanding solvent-ion-support systems. Although expansion in the presence of $\mathrm{H}_{2} \mathrm{O}$ is well known to be systematically correlated with the hydration free energy of the interlayer cation, in environments dominated by non-polar solvents (i.e. $\mathrm{CO}_{2}$ ), uptake into the interlayer is not well-understood. Using novel high pressure capabilities, we investigated the interaction of dry supercritical $\mathrm{CO}_{2}$ with $\mathrm{Na}^{+}-, \mathrm{NH}_{4}^{+}-$, and $\mathrm{Cs}^{+}$-saturated montmorillonite, comparing results with predictions from molecular dynamics simulations. Despite the known trend in $\mathrm{H}_{2} \mathrm{O}$, and that cation solvation energies in $\mathrm{CO}_{2}$ suggest a stronger interaction with $\mathrm{Na}^{+}$, both the $\mathrm{NH}_{4}{ }^{+}$- and $\mathrm{Cs}^{+}$-clays readily absorbed $\mathrm{CO}_{2}$ and expanded while the $\mathrm{Na}^{+}$-clay did not. The apparent inertness of the $\mathrm{Na}^{+}$-clay was not due to kinetics, as experiments seeking a stable expanded state showed that none exists. Molecular dynamics simulations revealed a large endothermicity to $\mathrm{CO}_{2}$ intercalation in the $\mathrm{Na}^{+}$-clay, but little or no energy barrier for the $\mathrm{NH}_{4}^{+}-$and $\mathrm{Cs}^{+}$-clays. Indeed, the combination of experiment and theory clearly demonstrate that $\mathrm{CO}_{2}$ intercalation of Na-montmorillonite clays is prohibited in the absence of $\mathrm{H}_{2} \mathrm{O}$. Consequently, we have shown for the first time that in the presence of a low dielectric constant gas swelling depends more on the strength of the interaction between interlayer cation and aluminosilicate sheets and less on that with solvent. The finding suggests a distinct regime in layered aluminosilicates swelling behavior triggered by low solvent polarizability, with important implications in geomechanics, storage and retention of volatile gases, and across industrial uses in gelling, decoloring, heterogeneous catalysis, and semipermeable reactive barriers.
\end{abstract}

\section{INTRODUCTION}

Layered aluminosilicates have unique properties that emerge from their quasi-2D structure, composition, permanent layer charge, and charge-balancing interlayer cations. As a primary source of nanoporosity ${ }^{1-2}$ gas absorptivity ${ }^{3-4}$, and ductility ${ }^{5}$ in sedimentary rocks, their specific behavior, even in small concentrations, can control the geomechanical response of caprocks that seal reservoir formations $^{6}$ or the extraction of natural gas from organic rich shales that are the source rocks driving the present fracking boom. ${ }^{7}$ They are also used widely in industrial applications that range from catalytic substrates ${ }^{8}$ to metal and gas sorbents ${ }^{9-10}$ to reactive barrier materials. ${ }^{11}$
A key characteristic is their ability to expand or contract by absorbing or ejecting solvent and ions in response to changing fluid chemistry. ${ }^{12}$ Layered aluminosilicates known as smectites are of particular interest, because they can swell substantially in the presence of certain volatiles ${ }^{13-14}$ due to incorporation of these species in their interlayer galleries. The extent to which swelling will be significantly altered when exposed to fracking fluids during gas extraction from shales and supercritical $\mathrm{CO}_{2}\left(\mathrm{scCO}_{2}\right)$ during and after injection of $\mathrm{CO}_{2}$ into geologic reservoirs is often a crucial unknown. ${ }^{15}$ Unlike swelling performance requirements for clay based barriers in nuclear repositories ${ }^{16}$, geologic exploration operations using non-aqueous based technologies (i.e. $\mathrm{scCO}_{2}$ ) are 
designed to avoid clay swelling ${ }^{17}$ to minimize threats to formation permeability.

Solvent selectivity in smectite swelling is not comprehensively well understood; while their swelling behavior when exposed to $\mathrm{H}_{2} \mathrm{O}$ is well known ${ }^{18-20}$, in multiphase and non-aqueous fluids questions remain regarding the underlying forces that lead to solvent uptake and expansion of the interlayer region. With respect to $\mathrm{H}_{2} \mathrm{O}$, the degree of $\mathrm{H}_{2} \mathrm{O}$ intercalation and induced swelling largely depends on the hydration free energy of the interlayer cation. $^{21-22}$ This is best demonstrated by comparing swelling behaviors of $\mathrm{Na}^{+}$montmorillonites ${ }^{19}$, which maintain two layers of hydration $(2 \mathrm{~W})$ to the identical clay containing $\mathrm{Cs}^{+}$, a so-called swelling hindrance interlayer cation, that restrict hydration to a $1 \mathrm{~W}$ state. ${ }^{21}$ With respect to weakly polar solvents such as $\mathrm{CO}_{2}$, recent laboratory studies have clearly demonstrated reversible volumetric transformations of smectite minerals due to exposure to gaseous $\mathrm{CO}_{2}\left(\mathrm{CO}_{2(\mathrm{~g})}\right)$ or $\mathrm{scCO}_{2} \cdot{ }^{13,23-30}$ For example, a number of studies ${ }^{13,28}$ have reported increased basal spacings when montmorillonite with less than a full layer of $\mathrm{H}_{2} \mathrm{O}$ molecules (sub $1 \mathrm{~W})$ was exposed to $\mathrm{scCO}_{2}$, evidence that $\mathrm{CO}_{2}$ enters the interlayer at least under relatively low $\mathrm{H}_{2} \mathrm{O}$ chemical potentials. A striking observation was that $\mathrm{H}_{2} \mathrm{O}$ and $\mathrm{CO}_{2}$ intercalation was both synergistic and competitive: fully collapsed Na-montmorillonite neither expanded nor sorbed $\mathrm{CO}_{2}$ into the interlayer region when exposed to dry $\mathrm{scCO}_{2} \cdot{ }^{26,31-33}$ However, small additions of $\mathrm{H}_{2} \mathrm{O}$ to $\mathrm{scCO}_{2}$ promoted $\mathrm{CO}_{2}$ intercalation up to a critical $\mathrm{H}_{2} \mathrm{O}$ concentration beyond which $\mathrm{H}_{2} \mathrm{O}$ expelled $\mathrm{CO}_{2}$ from the interlayer region. An intuitive explanation is that because the free energy of solvation for $\mathrm{H}_{2} \mathrm{O}-\mathrm{Na}^{+}$in the interlayer is expectedly larger than that for $\mathrm{Na}-\mathrm{CO}_{2}$, even at relatively low $\mathrm{H}_{2} \mathrm{O}$ concentrations hydrated or partially hydrated $\mathrm{Na}^{+}$essentially props the interlayers open, allowing $\mathrm{CO}_{2}$ to enter as secondary outcome. Indeed, calculated solvation energies for $\mathrm{Na}^{+}$in bulk water and $\mathrm{scCO}_{2}{ }^{34}$ show that the solvation energies for $\mathrm{Na}^{+}$in $\mathrm{scCO}_{2}$ are $\sim 50 \%$ less than for $\mathrm{Na}^{+}$in water. What is missing from such observations is a fundamental understanding of the behavior of the system in the complete absence of water. In other words, can nonpolar solvents, which do not have as strong an interaction with interlayer cations, drive open the interlayer space and, if so, why and under what conditions? A cation solvation-based interpretation alone ignores the importance of cation interaction with the aluminosilicate framework.

Probing the interactions of $\mathrm{CO}_{2}$, interlayer cations, and the aluminosilicate structural units within nano-crystallites, a common size range for these minerals, is challenging. Confinement in the nanometer-scale interlayer space may alter the equilibrium configurations of relevant species. Theoretical studies have provided some insight into energetic barriers to intercalation, solvation of interlayer cations by $\mathrm{CO}_{2}$, as well as the thermomechanical properties of clays. ${ }^{35-42}$ Calculations by Makaremi et al. ${ }^{40}$, in the absence of $\mathrm{H}_{2} \mathrm{O}$, suggest a large energy barrier for $\mathrm{CO}_{2}$ intercalation into a fully collapsed Na-montmorillonite at both supercritical and non-supercritical conditions. The results also show that an expanded state near $d(001)=\sim 12.3 \AA$ is metastable. The presence of an energy barrier to $\mathrm{CO}_{2}$ intercalation is consistent with the experiments discussed above. Whether a stable expanded state for Na-montmorillonite/ $\mathrm{CO}_{2}$ exists or not has never been determined experimentally.

Enabled by novel in situ capabilities, here we explore the balance between cation-aluminosilicate and cation- $\mathrm{CO}_{2}$ interactions with respect to $\mathrm{CO}_{2}$ intercalation and swelling. We vary interlayer monovalent cation radius by using $\mathrm{Na}^{+}, \mathrm{NH}_{4}{ }^{+}$, and $\mathrm{Cs}^{+}$to systematically tune the strength of the interaction with the aluminosilicate sheet and their solvation free energies with $\mathrm{CO}_{2}$. Similar to $\mathrm{H}_{2} \mathrm{O}$-cation interactions, classical molecular dynamics (MD) ${ }^{34}$ and high-level $a b$ initio calculations (Figure 1) suggest that $\mathrm{CO}_{2-}$ cation solvation energies decrease in magnitude with increasing cation size (or charge density) from $\mathrm{Na}^{+} \rightarrow \mathrm{Cs}^{+}$. However, the solvation energies for $\mathrm{CO}_{2}$-cation are on the order of $50 \%$ lower than for $\mathrm{H}_{2} \mathrm{O}$. Consequently, we hypothesize that the relatively low $\mathrm{CO}_{2}$-cation solvation energies will highlight the interaction of the interlayer cation with the aluminosilicate structural units. Three dry montmorillonites $\left(\mathrm{Na}^{+}, \mathrm{NH}_{4}^{+}\right.$, or $\mathrm{Cs}^{+}$saturated $\left.\mathrm{SWy}-2\right)$ were reacted with anhydrous $\mathrm{scCO}_{2}$ and characterized in detail in situ. If the clays with the larger cations $\left(\mathrm{NH}_{4}{ }^{+}\right.$or $\left.\mathrm{Cs}^{+}\right)$expand but Na-clay does not, then the expansion cannot be attributed to the strength of the solvent interaction with the interlayer cation but rather the strength of the cation interaction with aluminosilicate sheet surfaces. However, this observation would not unambiguously identify the cause of $\mathrm{CO}_{2}$ intercalation per se, because the propping effect of larger cations conceptually can enhance $\mathrm{CO}_{2}$ diffusivity and uptake. ${ }^{45}$ We directly test this by performing experiments that evaluate if the clay remains expanded or collapses once the "props" are removed, thus constraining the possible existence of a stable expanded state for the Na-montmorillonite $/ \mathrm{CO}_{2}$ system. Modifications to the clay structure were probed with $\mathrm{x}$ ray diffraction (XRD), while changes in the $\mathrm{CO}_{2}$ chemical environment were analyzed using infrared (IR) spectroscopy. Perturbations in the $\mathrm{CO}_{2}$ molecules in the interlayer, including information on $\mathrm{CO}_{2}$-cation interaction, were analyzed by magic angle spinning nuclear magnetic resonance (MAS-NMR) spectroscopy. All measurements were performed on the fluid/clay system in situ under controlled pressurized conditions. Molecular dynamics simulations at the same conditions using the Grand Canonical ensemble (GCMD) were used to map the free energy landscape as a function of $\mathrm{CO}_{2}$ intercalation and interlayer spacing for model $\mathrm{Na}^{+}, \mathrm{NH}_{4}^{+}$, and $\mathrm{Cs}^{+}$clay structures. Collectively, in contrast to swelling behavior in $\mathrm{H}_{2} \mathrm{O}$ systems, our findings demonstrate that cation-clay interactions play the commanding role relative to solvation of interlayer cations for clay expansion in weakly to non-polar solvents such as $\mathrm{CO}_{2}$.

\section{RESULTS AND DISCUSSION}

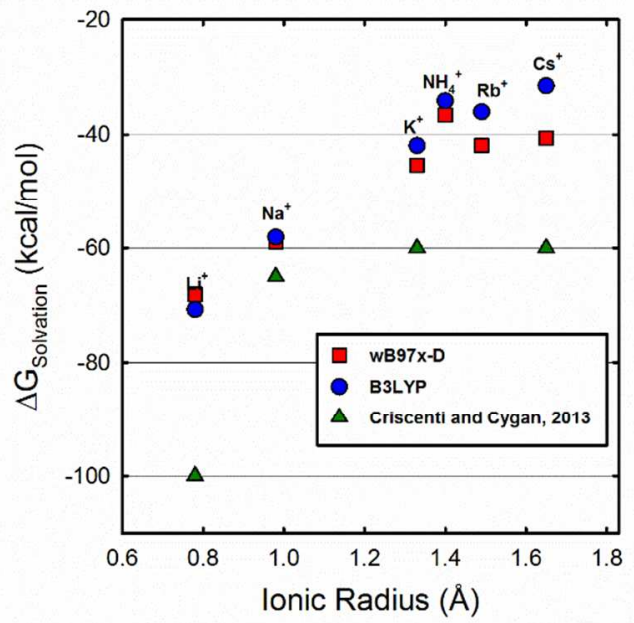

Figure 1. Free energy of solvation by $\mathrm{CO}_{2}$ versus ionic radius ${ }^{43-}$ 44 for alkali cations and the ammonium cation calculated using electronic structure calculations (see supplemental information). Also shown are values calculated by Criscenti and $\mathrm{Cy}-$ gan et al., ${ }^{34}$ using classical molecular dynamics simulations.

Pressurized X-ray Diffraction 
The $d(001)$ values of SWy-2 $\left(\mathrm{Na}^{+}, \mathrm{Cs}^{+}\right.$, and $\left.\mathrm{NH}_{4}^{+}\right)$were determined by XRD at atmospheric $\left(24^{\circ} \mathrm{C}\right.$ and $\left.\sim 35 \% \mathrm{RH}\right)$ and vacuum $\left(\sim 10^{-3}\right.$ Torr, $\left.50^{\circ} \mathrm{C}\right)$ conditions, and during exposure to $\mathrm{CO}_{2}$ at 90 bar $\left(50^{\circ} \mathrm{C}\right)$. The measured peak centroids of the $\mathrm{d}(001)$ basal reflections are listed in Table 1 (see Figure S1 for the XRD tracings). The range of values for $d(001)$ under atmospheric conditions $(\sim 35 \% \mathrm{RH})$ are consistent with those reported in the literature for nominally the same clays and similar conditions. ${ }^{18,46-48}$

The $d(001)$ values for all the clays decreased when exposed to vacuum $\left(10^{-3}\right.$ Torr, $\left.50^{\circ} \mathrm{C}\right)$, indicating the removal of interlayer water. The $d(001)$ value $(9.75 \AA)$ for $\mathrm{Na}-\mathrm{SWy}-2$ is slightly larger than the reported value $(9.66 \AA)$ for a completely dehydrated $\mathrm{Na}-$ SWy- $1 ;{ }^{19}$ where the $\mathrm{Na}^{+}$cations are coordinated by six basal oxygen atoms. $^{46,49}$ The larger $d(001)$ value $(11.13 \AA)$ for Cs-SWy-2 correlates with the relatively larger size of the $\mathrm{Cs}^{+}$cation (Cs: $1.69 \AA, \mathrm{Na}: 0.95 \AA$, and $\left.\mathrm{NH}_{4}: 1.43 \AA\right)^{50-51}$. Calculated and experimental $d(001)$ values from the literature show a significant range for dehydrated Cs-montmorillonite. For example, Bérend et al., ${ }^{18}$ cite values from 10.7 to $11.35 \AA$; their own experimental work on Cs-SWy-1 yielded $d(001)=11.08 \AA$ (exposed to vacuum at 100 ${ }^{\circ} \mathrm{C}$ for 4-24 hours). Simulations of anhydrous $\mathrm{Cs}^{+}$smectites consistently yield smaller $d(001)$ values compared to experiment, with spacings ranging from 10.50 to $10.70 \AA .{ }^{48,52-53}$ The $d(001)$ values for $\mathrm{NH}_{4}-\mathrm{SWy}-2$ reported here are intermediate (10.39$10.49 \AA$ ) with respect to the $\mathrm{Na}^{+}$and $\mathrm{Cs}^{+}$clays. Gautier et al. ${ }^{47}$ also analyzed an anhydrous $\mathrm{NH}_{4}-\mathrm{SWy}-2$ sample and reported $d(001)=\sim 10.4 \AA$, consistent with the present study. ${ }^{54}$

Both $\mathrm{Cs}^{+}$and $\mathrm{NH}_{4}{ }^{+}$montmorillonite expanded during exposure to $\mathrm{scCO}_{2}$, but $\mathrm{Na}^{+}$montmorillonite did not (Table 1). Other than peak intensity attenuation from the dense $\mathrm{CO}_{2}$ fluid, the patterns for $\mathrm{Na}^{+}$montmorillonite were essentially identical under vacuum and exposure to $\mathrm{scCO}_{2}$ (see Figure S1-S3). When the pressurized experiments were opened to the vacuum for a few minutes, the $\mathrm{Cs}^{+}$and $\mathrm{NH}_{4}^{+}$clays collapsed back to their original vacuum basal spacing with no sign of alteration or secondary phase formation.

Table 1. Measured and [calculated] $d(001)$ basal spacing $(\AA)$ for cation saturated $\mathrm{SWy}-2$ clays while exposed to atmospheric conditions $\left(24^{\circ} \mathrm{C}\right)$, vacuum $\left(10^{-3}\right.$ Torr, $\left.50^{\circ} \mathrm{C}\right)$, and $\mathrm{CO}_{2}\left(90 \mathrm{bar}, 50^{\circ} \mathrm{C}\right)$.

\begin{tabular}{|c|c|c|c|c|}
\hline & & atmosphere & Vacuum & $\mathbf{C O}_{\mathbf{2}}$ \\
\hline Clay & Cation & $\mathbf{1 . 0}$ bar & $\mathbf{( 1 0}^{-3}$ Torr $)$ & $\mathbf{9 0}$ bar \\
\hline \multirow{3}{*}{ SWy-2 } & $\mathrm{Cs}$ & 12.30 & 11.13 & 12.03 \\
\cline { 2 - 5 } & $\mathrm{NH}_{4}$ & 12.10 & 10.39 & 11.50 \\
\cline { 2 - 5 } & $\mathrm{Na}$ & 12.10 & 9.75 & 9.75 \\
\hline
\end{tabular}

\section{Pressurized MAS NMR}

${ }^{13} \mathrm{C}$
The ${ }^{13} \mathrm{C}$ MAS NMR resonances for the pure $\mathrm{scCO}_{2}$ and $\mathrm{scCO}_{2}$ plus $\mathrm{Na}^{+}$montmorillonite systems (Figure 2) are characterized by narrow center bands at $\sim 124 \mathrm{ppm}$ with full widths at half height (FWHH) of $\sim 0.11 \mathrm{ppm}$. These narrow peaks reflect rapid, isotropic tumbling of $\mathrm{CO}_{2}$ molecules in the supercritical fluid. There are also pairs of small spinning sidebands (SSBs). For pure $\mathrm{scCO}_{2}$, these SSBs are likely associated with $\mathrm{CO}_{2}$ either adsorbed to or being compressed on the rotor wall due to the centrifugal forces caused by the rotor rotation at $\sim 3 \mathrm{kHz}$.

For Na-SWy-2- $\mathrm{ScCO}_{2}$, they are likely to arise from similar effects, given that their intensities are similar to those for $\mathrm{scCO}_{2}$. Although they may also be associated with a small fraction of $\mathrm{CO}_{2}$ weakly adsorbed to the exterior surfaces of clay particles. ${ }^{55}$

The center bands for the $\mathrm{NH}_{4}$ - and Cs-SWy-2 are also at $\sim 124$ $\mathrm{ppm}$, demonstrating that the resonance comes from $\mathrm{CO}_{2}$. However, the increased peak widths (FWHHs: $\sim 0.31 \mathrm{ppm}$ ) indicate greater interaction of the $\mathrm{CO}_{2}$ with solid surfaces and are consistent with greater restriction of $\mathrm{CO}_{2}$ mobility. The SSB patterns are similar for the $\mathrm{NH}_{4}$ - and $\mathrm{Cs}-\mathrm{SWy}-2$ samples and are more intense with greater basal widths than for Na-SWy-2, showing four well resolved SSBs. The spans of the chemical shift anisotropy (CSA) for the $\mathrm{NH}_{4}$ - and Cs-SWy-2 are at least $160 \mathrm{ppm}$ with a negative skew in each case. As discussed by Bowers et al., ${ }^{32}$ the SSBs are assigned to interlayer $\mathrm{CO}_{2}$ molecules adsorbed in a 1WL-type $(\sim 12.5 \AA)$ interlayer with the O-C-O molecular axes oriented parallel to the basal clay surface on average and experiencing rapid $\left(>10^{5} \mathrm{~Hz}\right)$ reorientation about an axis normal to the

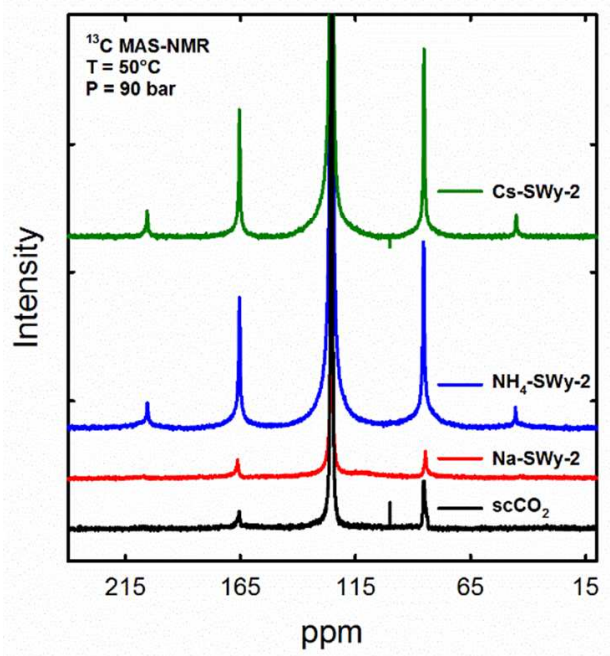

Figure 2. ${ }^{13} \mathrm{C}$ MAS NMR spectra of neat $\mathrm{scCO}_{2}, \mathrm{Na}-\mathrm{SWy}-2$ $\mathrm{scCO}_{2}, \mathrm{NH}_{4}-\mathrm{SWy}-2-\mathrm{scCO}_{2}, \mathrm{Cs}-\mathrm{SWy}-2-\mathrm{scCO}_{2}$ vertically expanded to highlight the spinning sideband patterns. Note that the $\mathrm{Cs}^{+}-$ and the $\mathrm{NH}_{4}^{+}$- clays show evidence of interlayer-adsorbed $\mathrm{CO}_{2}$ in the SSB patterns, whereas the $\mathrm{Na}^{+}$saturated clay shows no evidence of interlayer $\mathrm{CO}_{2}$.

clay basal surface. ${ }^{55}$

${ }^{133} \mathrm{Cs}$

The ${ }^{133} \mathrm{Cs}$ NMR spectrum of Cs-SWy-2 at $50^{\circ} \mathrm{C}$ and 1 bar $\mathrm{N}_{2}$ contains a broad center band at $\sim 43 \mathrm{ppm}$ and a well-developed SSB pattern (Figure 3). The broad peaks and broad spinning sideband manifold arise from strong paramagnetic coupling between ${ }^{133} \mathrm{Cs}^{+}$and structural $\mathrm{Fe}$ in $\mathrm{SWy}-2,{ }^{56}$ consistent with the $\mathrm{Cs}^{+}$ being close to the basal surfaces in collapsed interlayers. ${ }^{53}$ These results are similar to those reported by Weiss et al., ${ }^{57}$ and others. $^{49,52}$ 


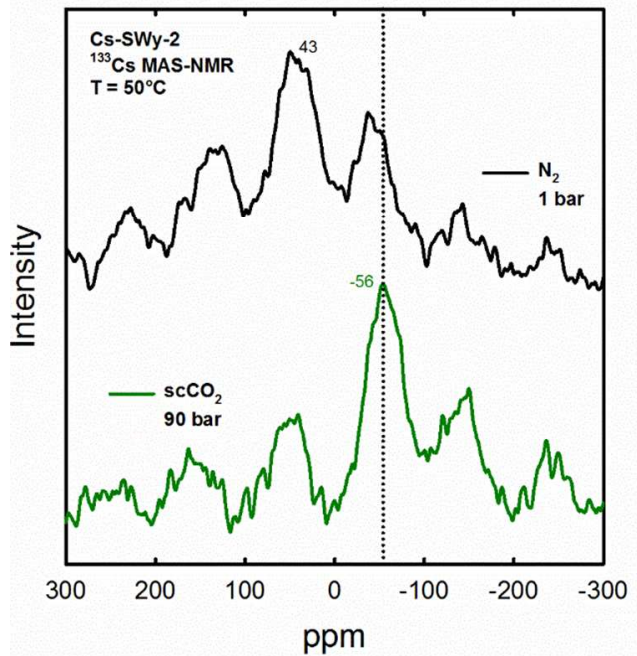

Figure 3. ${ }^{133} \mathrm{Cs}$ MAS NMR spectra of Cs-SWy-2 (top) and Cs$\mathrm{SWy}-2-\mathrm{scCO}_{2}$, (bottom). Note the increase in area of the central peak due to $\mathrm{CO}_{2}$-coordinated interlayer $\mathrm{Cs}^{+}(-56 \mathrm{ppm})$.

Following exposure to $\mathrm{scCO}_{2}$, the ${ }^{133} \mathrm{Cs}$ centerband for Cs-SWy-2 shifts to $-56 \mathrm{ppm}$ but the strong SSB pattern remains. The full widths at half maximum of the centerband and spinning sidebands are very similar for both conditions $\left(16 \pm 9 \mathrm{ppm}\right.$ pre- $\mathrm{CO}_{2}$ and 13 \pm 5 ppm post- $\mathrm{CO}_{2}$ ). However, the baseline flattens and the standard deviations of the FWHH decrease for the sample exposed to $\mathrm{scCO}_{2}$. We interpret these changes to be due to reduced paramagnetic interaction with structural $\mathrm{Fe}$ in the clay as the distance between $\mathrm{Cs}$ and $\mathrm{Fe}$ increases with interlayer expansion. It is more difficult to comment on changes in the peak area since the magnitude of the quadropolar coupling and paramagnetic coupling are both changing as the coordination environment changes. The large change in the position of the ${ }^{133} \mathrm{Cs}$ center band is well correlated to the XRD data (Table 1) and previous studies of Cshectorite $^{32}$, and reflects a change in the coordination environment of $\mathrm{Cs}^{+}$due to some combination of interlayer expansion and $\mathrm{Cs}^{+}$ solvation by $\mathrm{CO}_{2}$.

${ }^{15} \mathrm{~N}$

The ${ }^{15} \mathrm{~N}$ MAS NMR spectra of $\mathrm{NH}_{4}-\mathrm{SWy}-2$ show an appreciable increase in intensity, a small change in chemical shift, and little change in peak width after exposure to $\mathrm{scCO}_{2}(6.0 \pm 0.4 \mathrm{ppm}$ without vs. $6.3 \pm 0.6 \mathrm{ppm}$ with) (Figure 4). With and without $\mathrm{CO}_{2}$ the spectra contain one center band and four SSBs distributed symmetrically about the center band. In the presence of $\mathrm{scCO}_{2}$, the central peak shifts from $-13.1 \pm 0.1 \mathrm{ppm}$ to $-14.5 \pm 0.1$ ppm, and the intensities of the central peak and SSBs increase dramatically, with the absolute intensity of the center band increasing by more than a factor of three during exposure to $\mathrm{scCO}_{2}$. The increase in intensity reflects greater dynamic motion of the $\mathrm{NH}_{4}{ }^{+}$cations due to interlayer expansion as $\mathrm{CO}_{2}$ intercalates the clay, likely the result of more rapid $\mathrm{NH}_{4}^{+}$reorientation about the axes of molecular symmetry. As for the Cs-clay, we attribute the changes in the ${ }^{15} \mathrm{~N}$ MAS NMR signal, which parallel the XRD results, to a combination of interlayer expansion and $\mathrm{CO}_{2}$ solvation.

${ }^{23} \mathrm{Na}$

The ${ }^{23} \mathrm{Na}$ MAS NMR spectrum of Na-SWy-2 at one bar $\left(\mathrm{N}_{2}\right)$ is dominated by a broad central peak and broad SSBs, consistent with $\mathrm{Na}^{+}$experiencing paramagnetic coupling to structural $\mathrm{Fe}$ (Figure 5). ${ }^{56}$ In contrast to the $\mathrm{Cs}-$ and $\mathrm{NH}_{4}$ - samples, there is no significant change in the ${ }^{23} \mathrm{Na}$ signal after exposure to $\mathrm{scCO}_{2}$,

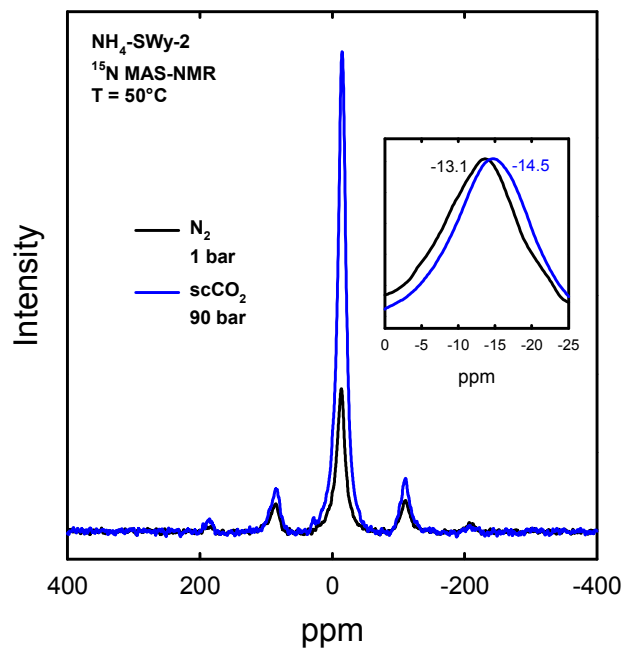

Figure 4. ${ }^{15} \mathrm{~N}$ MAS NMR spectra of $\mathrm{NH}_{4}-\mathrm{SWy}-2$ before (bottom) and during (top) exposure to $\mathrm{scCO}_{2}$, plotted on the same absolute intensity scale.

paralleling the XRD and ${ }^{13} \mathrm{C}$ NMR results that also show no changes during exposure to $\mathrm{scCO}_{2}$. The better signal/noise ratio for the sample exposed to $\mathrm{scCO}_{2}$ simply reflects longer acquisition times. Consequently, the ${ }^{23} \mathrm{Na}$ NMR spectrum clearly indicates that $\mathrm{CO}_{2}$ does not intercalate dry Na-SWy-2. Accounting for the field-dependent quadrupolar shift of ${ }^{23} \mathrm{Na}$, these results are very similar to those for dry Na-montmorillonite ${ }^{58}$ and dry Nahectorite..$^{59,60}$

\section{Molecular Dynamics Simulations}

Molecular dynamics simulations were conducted in the grand canonical ensemble ${ }^{61}$ for model $\mathrm{Na}^{+}, \mathrm{Cs}^{+}-, \mathrm{NH}_{4}^{+}{ }^{+}$ montmorillonite (SWy-2) with imposed basal spacings using the RASPA software package. ${ }^{62}$ The computed interlayer $\mathrm{CO}_{2}$ contents and associated immersion energies of the SWy-2 clay systems vary significantly depending on the exchangeable cation (Figure 6). For Na-SWy-2, interlayer adsorption of $\mathrm{CO}_{2}$ molecules begins only after the $\mathrm{d}(00 l)$ basal spacing is substantially increased from the collapsed state at $9.5 \pm 0.1 \AA$ (vertical black

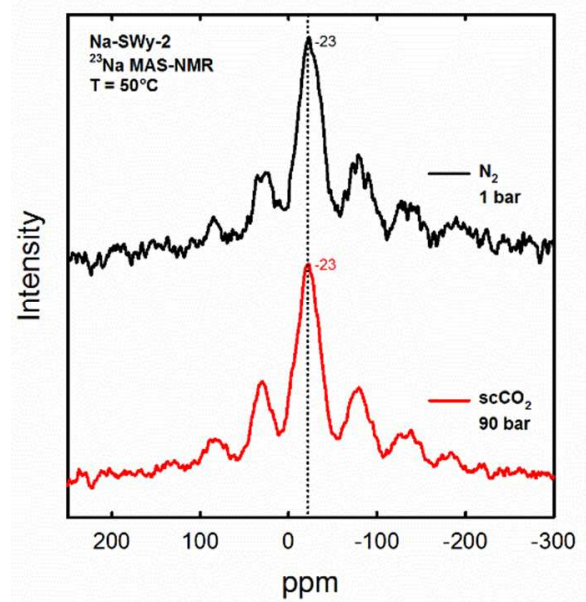

Figure 5. ${ }^{23} \mathrm{Na}$ MAS NMR of Na-SWy-2 (top) and Na-SWy-2$\mathrm{scCO}_{2}$ (bottom). Note the absence of any change in position or intensity of the central peak at $-23 \mathrm{ppm}$ in the presence of $\mathrm{scCO}_{2}$.

line in Figure 6) $)^{46,48}$ to $>10.7 \AA$. Consequently, the immersion energy increases from $d(001)=9.5 \AA$ to $10.7 \AA$, predicting that the 
collapsed state is stable relative to the $1 \mathrm{WL}$ state and that there is a significant energetic barrier to $\mathrm{CO}_{2}$ intercalation. This conclusion is consistent with previous molecular simulations by Makaremi et al. ${ }^{40}$ Consequently, the modeling results are in accord with the experiments that showed no change in the basal spacing (Table 1) or ${ }^{23} \mathrm{Na}$ NMR signal upon exposure to $\mathrm{scCO}_{2}$.
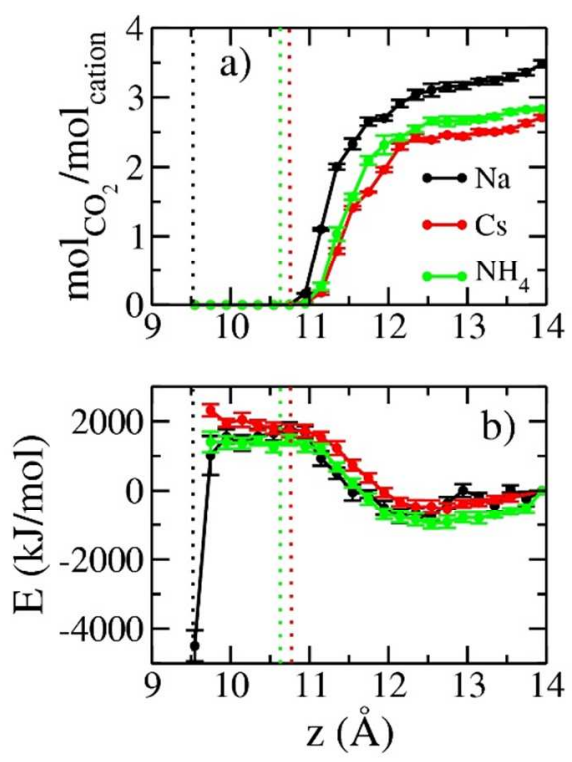

Figure 6. $\mathrm{CO}_{2}$ content (a) and immersion energy of the system (b) as a function of basal spacing for SWy-2. The solid line at $9.5 \AA, 10.6 \AA$, and $10.7 \AA$ indicate the collapsed basal spacing of $\mathrm{Na}^{+}$(black), $\mathrm{NH}_{4}^{+}$(green), and $\mathrm{Cs}^{+}$(red) clays, respectively. The error bars show the $95 \%$ confidence level. The reference state for the immersion energies is the $14.0 \AA$ basal spacing.

The computed $d(001)$ value for fully collapsed Cs-SWy-2 (10.7 \pm $0.2 \AA$; red vertical dotted line in Figure 6a and b) is similar to previous calculated values ${ }^{48,52-53}$, but slightly less than experimental values (Table 1 and cited literature ${ }^{18,47-48}$ ). The calculated $d(001)$ value for fully collapsed $\mathrm{NH}_{4}-\mathrm{SWy}-2(10.6 \pm 0.2 \AA$; delineated by the green vertical dotted lines in Figure $6 \mathbf{a}$ and $\mathbf{b})$ is slightly larger than the experimentally determined value $(10.39$ $\AA)$. For both the $\mathrm{Cs}$ - and $\mathrm{NH}_{4}$-systems the immersion energies of 1WL states $(\sim 12.5 \AA)$ are significantly less than collapsed states, and there is no energy barrier to $\mathrm{CO}_{2}$ intercalation (Figure 6a). For instance, the immersion energy decreases from $\sim 1700 \mathrm{~kJ} / \mathrm{mol}$ $(10.7 \AA)$ to $\sim-500 \mathrm{~kJ} / \mathrm{mol}(12.5 \AA)$ for Cs-SWy-2, while, the energy decreases from $\sim 1400 \mathrm{~kJ} / \mathrm{mol}(10.6 \AA)$ to $\sim-800 \mathrm{~kJ} / \mathrm{mol}(12.5 \AA)$ with $\mathrm{NH}_{4}-\mathrm{SWy}-2$. Consequently, and in contrast to $\mathrm{Na}-\mathrm{SWy}-2$, the simulations indicate that $\mathrm{CO}_{2}$ should readily enter the interlayer galleries of $\mathrm{NH}_{4}$ - and Cs-montmorillonites and form a stable expanded state $(\sim 12.5 \AA)$, in agreement with the XRD and NMR results.

The computed basal spacings of the $1 \mathrm{WL}$ states of $\mathrm{NH}_{4}$ - and CsSWy-2 at $d(001)=\sim 12.5-12.6 \AA$ are larger than the corresponding experimental values of 11.50 and $12.03 \AA$ (Table 1). The models and experiments also showed somewhat different $d(001)$ values for the fully collapsed clays (Table 1). In this regard, the calculated energy wells for the stable expanded states (around $\sim 12.5 \AA$ ) are broad and, consequently, the minimum energy $d(001)$ values are not precisely known. Likewise, the simulations yielded energy plateaus for $\mathrm{NH}_{4}$ - and $\mathrm{Cs}-\mathrm{SWy}-2$ around the stable collapsed spacings $\left(10.6 \AA-\mathrm{NH}_{4}\right.$ and $\left.10.7 \AA-\mathrm{Cs}-\mathrm{SWy}-2\right)$ and it is difficult to precisely determine the minimum energy $d(001)$ in this region. In addition, the immersion energies show very little difference in magnitude $(\sim 1600 \mathrm{~kJ} / \mathrm{mol})$ between their collapsed state and at distances when $\mathrm{CO}_{2}$ intercalation begins with $\mathrm{Cs}-$ and $\mathrm{NH}_{4}-\mathrm{SWy}-$ $2(\sim 10.9 \AA)$. It is also possible that the experiments did not reach equilibrium and record metastable states beyond the resolution of the simulations. We did not investigate energy versus $d(001)$ behavior below $9.6 \AA$ for the $\mathrm{Na}^{+}$clay.

Simulations indicate an equilibrium $1 \mathrm{WL}(\sim 12.5 \AA)$ interlayer $\mathrm{CO}_{2}$ content for $\mathrm{NH}_{4}-\mathrm{SWy}-2\left(2.61 \mathrm{~mol} \mathrm{CO} / \mathrm{mol} \mathrm{NH}_{4}{ }^{+}\right)$that is slightly greater than for Cs-SWy-2 (2.40 mol CO $\left.\mathrm{CO}_{2} / \mathrm{mol} \mathrm{Cs}^{+}\right)$ (Figure 6a) and that both are less than the value for the metastable $1 \mathrm{WL}$ state of the $\mathrm{Na}^{+}$clay $\left(2.99 \mathrm{~mol} \mathrm{CO} 2 / \mathrm{mol} \mathrm{Na}^{+}\right)$. Recall, however, that $\mathrm{CO}_{2}$ is not thermodynamically favored to intercalate the dry $\mathrm{Na}^{+}$clay; in this case, small concentrations of interlayer $\mathrm{H}_{2} \mathrm{O}$ are required for $\mathrm{CO}_{2}$ intercalation. ${ }^{26,30}$

The energetic contribution from different interacting pairs involved during $\mathrm{CO}_{2}$ intercalation with all $3 \mathrm{SWy}-2$ were examined to better understand the reason for the different behaviors of these clays. Figure 7 clearly illustrates that the primary cause for the large intercalation energy barrier for $\mathrm{CO}_{2}$ with and the high stability of the collapsed state for Na-Swy-2 arises from the strong interaction of $\mathrm{Na}$ with the clay in contrast to the $\mathrm{NH}_{4}$ and Csmodels. In particular, the difference in the $\mathrm{Na}$ /clay interaction energies between the collapsed state $(9.5 \AA)$ and at the transition state for $\mathrm{CO}_{2}$ intercalation $(\sim 10.8 \AA$ ) is $\sim 125 \mathrm{~kJ} / \mathrm{mol}$ (Figure $7 \mathrm{a}$ ). In contrast, the difference in interaction energies for $\mathrm{NH}_{4} /$ clay and $\mathrm{Cs} /$ Clay between their collapsed states $\left(10.6 \AA-\mathrm{NH}_{4}, 10.7 \AA-\mathrm{Cs}\right)$ and their transition states for $\mathrm{CO}_{2}$ intercalation $(\sim 10.9 \AA)$ is negli-
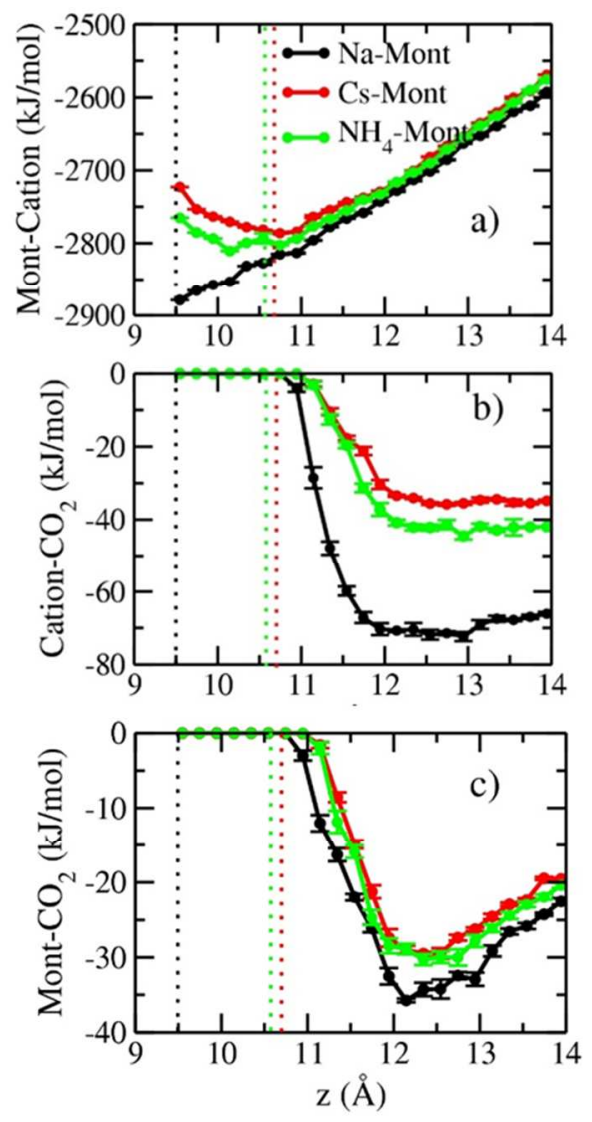

Figure 7. Variation in interaction energies between 3 different pairs. a) (SWy-2-Cation); b) Cation - $\mathrm{CO}_{2}$; c) $\mathrm{SWy}-2-\mathrm{CO}_{2}$ as functions of interlayer spacing for Na-, Cs- and $\mathrm{NH}_{4}-\mathrm{SWy}-2$ at $323 \mathrm{~K}$ and 90 bar. Dotted vertical lines indicate respective collapsed interlayer distances for cations. 
gible. At $d(001)$ values $>10.7 \AA$ the interaction energies for $\mathrm{Na} / \mathrm{CO}_{2}$ are significantly larger than for $\mathrm{Cs} / \mathrm{CO}_{2}$ and $\mathrm{NH}_{4} / \mathrm{CO}_{2}$, consistent with the solvation energy trends reported in Figure 1. Further, $\mathrm{CO}_{2}$ /clay interaction energies are relatively similar for all the cations (Figure 7c). The small, but significantly more favorable $\mathrm{CO}_{2}$ /clay interaction for Na-SWy-2 (Figure 7c) might reflect the stronger $\mathrm{CO}_{2} / \mathrm{Na}$ interaction energy (Figure 7b). Lastly, the sum of $\mathrm{CO}_{2} / \mathrm{Na}$ and $\mathrm{CO}_{2} /$ clay interaction energies is always less favorable than the $\mathrm{Na}$ /clay interaction energy from the collapsed state up to the metastable state. Thus, the simulations indicate that it is the strong interaction of $\mathrm{Na}^{+}$with the clay that inhibits $\mathrm{CO}_{2}$ intercalation and the relatively weak interaction of Cs and $\mathrm{NH}_{4}$ with the clay that facilities $\mathrm{CO}_{2}$ intercalation, in accord with experiment.

Quartz crystal microbalance (QCM) gas sorption measurements and discrete IR measurements (see Supplemental Information for details) were used to quantify the amount of interlayer $\mathrm{CO}_{2}$ under the experimental conditions to compare to the calculated concentrations. While these experimental techniques cannot distinguish external from intercalated $\mathrm{CO}_{2}$, the measurements help to validate the simulation results. Indeed, the IR intensity associated with the asymmetrical $\mathrm{CO}_{2}$ band (Figure 8) trends with the simulations if we use the experimental $d(001)$ values in Table 1 to calculate the sorbed $\mathrm{CO}_{2}$ concentrations from the simulation results plotted in Figure 6a. Similarly, these computed concentrations of $\mathrm{CO}_{2}(0.0$ $\mathrm{mol} \mathrm{CO} 2 / \mathrm{mol} \mathrm{Na}{ }^{+}, 1.55 \mathrm{~mol} \mathrm{CO} / \mathrm{mol} \mathrm{NH}_{4}{ }^{+}$, and $1.99 \mathrm{~mol}$ $\left.\mathrm{CO}_{2} / \mathrm{mol} \mathrm{Cs}^{+}\right)$trend well with our QCM measurements $(0.5 \mathrm{~mol}$ $\mathrm{CO}_{2} / \mathrm{mol} \mathrm{Na}^{+}, 1.74 \mathrm{~mol} \mathrm{CO} / \mathrm{mol} \mathrm{NH}_{4}{ }^{+}$, and $3.66 \mathrm{~mol} \mathrm{CO}{ }_{2} / \mathrm{mol}$ $\mathrm{Cs}^{+}$). We suggest that the higher values for the QCM measured results are due to detection of both external and intercalated $\mathrm{CO}_{2}$, whereas the simulations only quantify intercalated $\mathrm{CO}_{2}$.

\section{Is there a stable expanded state for Na-clay?}

The immersion energy plots for Na-SWy-2 (Figure 6b) indicate that the collapsed basal spacing $(9.5 \AA)$ is the most stable state, with energy minimum of $\sim-4500 \mathrm{~kJ} / \mathrm{mol}$ when compared to -700

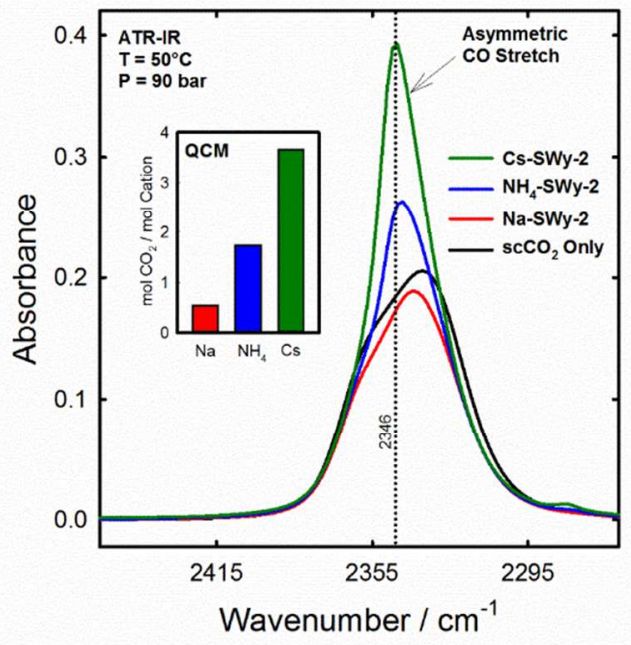

Figure 8. IR spectra in the asymmetric $\mathrm{CO}$ stretching of $\mathrm{CO}_{2}$ in the presence of Na-, Cs-, and $\mathrm{NH}_{4}-\mathrm{SWy}-2$ at 90 bar and $50^{\circ} \mathrm{C}$. Also shown for comparison is that spectrum of bulk $\mathrm{scCO}_{2}$ under the same conditions.

$\mathrm{kJ} / \mathrm{mol}$ hypothetical metastable state at $\sim 12.5 \AA$, in agreement with Makaremi et al., ${ }^{20}$ and our own calculations. To verify the computational results, we performed a series of high pressure IR experiments using an initially hydrated 1WL Na-SWy-2, a composition known to facilitate $\mathrm{CO}_{2}$ intercalation (see SI), ${ }^{26}$ and then systematically dehydrated the clay. The hydrated clay was first exposed to $\mathrm{scCO}_{2}$ at 90 bars and $50^{\circ} \mathrm{C}$ and then cycled between 90 and 180 bars at constant temperature, where the fluid was leaked out of the cell on each down-pressure leg of the cycle and fresh $\mathrm{CO}_{2}$ injected on every upward-pressure leg. The results show that as the clay dehydrated, eventually to the collapsed state $(9.67 \AA)$, intercalated $\mathrm{CO}_{2}$ was systematically and nearly completely expelled from the interlayer region. We then performed a similar experiment except the clay was cycled between $\mathrm{scCO}_{2}$ at 90 bars and $50^{\circ} \mathrm{C}$, and liquid $\mathrm{CO}_{2}$ at 90 bars and $25^{\circ} \mathrm{C}$, with $\mathrm{CO}_{2}+\mathrm{H}_{2} \mathrm{O}$ leaked on the upward-temperature leg of the cycle and fresh $\mathrm{ChyO}_{2}$ injected on every down-pressure leg. The results were the same: As the clay dehydrated, $\mathrm{CO}_{2}$ was expelled from the interlayer region. Consequently, these experiments are in agreement with our GCMD calculations and the computed results of Makaremi et al., ${ }^{40}$ showing that the collapsed state of Namontmorillonite is the stable state in equilibrium with dry $\mathrm{scCO}_{2}$.

\section{CONCLUSION and IMPLICATIONS}

Experiments and complementary GCMD simulations for Na-, $\mathrm{NH}_{4}{ }^{-}$and Cs-SWy-2 exposed to dry $\mathrm{scCO}_{2}$ at $50^{\circ} \mathrm{C}$ and 90 bars reveal that because this weakly polar solvent does not strongly solvate the interlayer cations the tendency to intercalate and swell is controlled instead by the strength of the cation interaction with the aluminosilicate sheets. The stable state of the Na-clay is the fully collapsed interlayer region with no intercalated $\mathrm{CO}_{2}$. Further, the Na-clay exhibits a large energy barrier for $\mathrm{CO}_{2}$ intercalation. In contrast, the stable state of the $\mathrm{NH}_{4}$ - and Cs-clay is an expanded, $1 \mathrm{WL}$-like state, containing substantial interlayer $\mathrm{CO}_{2}$, coupled with little to no energy barrier for $\mathrm{CO}_{2}$ diffusion into the interlayer region. The combination of experiment and theory demonstrates, for the first time, that it is the cation-clay interaction that determines the extent of interlayer expansion and absorption of relatively low dielectric volatiles by swelling clays. This is in contrast to cation $-\mathrm{H}_{2} \mathrm{O}$ interactions, where the hydration energy of the cation dominates interlayer expansion behavior. In addition to the cationic radius to charge characteristics, this also suggests that clay swelling in weakly polar solvents will be more sensitive to the layer charge and its distribution between tetrahedral and octahedral sites compared to $\mathrm{H}_{2} \mathrm{O}$-containing systems.

\section{EXPERIMENTAL SECTION}

The smectite used in our studies, Wyoming bentonite (SWy-2) was obtained from the Source Clays Repository of the Clay Mineral Society (Purdue University, www.agry.purdue.edu/cjohnston/sourceclays). The as-received SWy-2 clay was processed using the procedures of Loring et al., ${ }^{26}$ and saturated with $\mathrm{Na}^{+}, \mathrm{NH}_{4}^{+}$, or $\mathrm{Cs}^{+}$. For the XRD, dilute clay suspensions were prepared by suspending the cation saturated clays in water. NMR experiments required dry powders, which were obtained by drying clay suspensions on glass slides at room temperature. The resulting clay films were scraped off with a razor blade and placed into glass vials. The clays were characterized by XRD while either under vacuum or during exposure to $\mathrm{CO}_{2}$ (3.45 or 90 bar) at $50^{\circ} \mathrm{C}$ using a high pressure and temperature X-ray diffraction technique described previously. ${ }^{13,55}$ Initially, measured aliquots of dilute clay suspensions were pipetted onto a beryllium post, each occupying a circular area with an approximate diameter of 2-3 $\mathrm{mm}$. Each clay mount was allowed to air dry to produce a thin preferentially oriented clay film. The alignment process consisted of placing the beryllium post onto the XYZ stage and with the aid of the laser alignment system, manipulating the stage to expose only one clay film at a time to the XRD beam. Once the coordinates were established, the pressurized reactor was assembled, mounted into the instrument, and heated to $50^{\circ} \mathrm{C}$. Subsequent exposure to vacuum for 30 minutes removed most of the water from the clays. Pressurization with 
$\mathrm{CO}_{2}$ was accomplished through an ISCO pump connected directly to the reactor. Patterns were collected using a Bruker D8 Discover XRD instrument with a rotating $\mathrm{Cu}$ anode $(\mathrm{CuK}$ alpha $=1.5418$ $\AA$ ), programmable XYZ customized stage, and a Vantec 500 detector set at a sample-to-detector distance of $15 \mathrm{~cm}$. This instrument, operated at $50 \mathrm{kV}$ and $24 \mathrm{~mA}$, is capable of producing an intensely focused $0.5 \mathrm{~mm}$ beam. The resulting XRD patterns had an acquisition time of 300 seconds, were integrated over a range of $4-45^{\circ} 2 \theta$, and subsequently analyzed with the MDI JADE ${ }^{\mathbb{R}}$ XRD software package (Materials Data Inc, Livermore, Ca, $64550)$ to obtain peak positions.

${ }^{13} \mathrm{C},{ }^{23} \mathrm{Na},{ }^{15} \mathrm{~N}$, and ${ }^{133} \mathrm{Cs}$ MAS NMR spectra were collected under pressurized conditions at 90 bar $\mathrm{CO}_{2}$ and $50^{\circ} \mathrm{C}$ after first exposing each sample to dry nitrogen at $50^{\circ} \mathrm{C}$ and 1 bar. The NMR spectra were acquired at an $\mathrm{H}_{0}$ magnetic field of $7.0 \mathrm{~T}$ with a Varian VNMRS console. The solid-state probe was a $7.5 \mathrm{~mm}$ HXMAS Chemagnetics style probe with a ceramic housing. The zirconia rotors were altered and fitted with gas tight valves for pressurization. The ${ }^{13} \mathrm{C}$ MAS NMR data were acquired using a standard Bloch-decay pulse sequence with a pi/2 pulse width of $7.75 \mathrm{mi}-$ croseconds to obtain 700 transients. These data involved a spectral width of $50 \mathrm{kHz}$, a number of points per transient of $30 \mathrm{k}$, and a spin rate of approximately $3 \mathrm{kHz}$. The ${ }^{133} \mathrm{Cs}$ data were referenced to a $0.1 \mathrm{M}$ solution of $\mathrm{CsCl}$ using a secondary standard of $\mathrm{CsCl}$ (s). Spectra represent Bloch-decay data acquired using a spectral width of $\sim 200 \mathrm{kHz}, 18 \mathrm{k}-28 \mathrm{k}$ transients, a spin rate of 3.5 $\mathrm{kHz}, \pi / 2$ pulse width of $8 \mu \mathrm{s}$, and a pulse delay of $0.5 \mathrm{~s}$. The ${ }^{15} \mathrm{~N}$ data were also acquired with a Bloch-decay pules sequence with a $\pi / 2$ pulse width of $7 \mu \mathrm{s}$, a spectral width of $100 \mathrm{kHz}$, pulse delay of $1 \mathrm{~s}$, and a spin rate of $3 \mathrm{kHz}$ to obtain 5000 transients. The ${ }^{23} \mathrm{Na}$ data were acquired using a standard quadrupolar echo sequence to improve flatness of the baseline. These data sets involved acquiring $\sim 5 \mathrm{k}$ transients for the low pressure sample and $10 \mathrm{k}$ transients for the sample exposed to $\mathrm{scCO}_{2}$. Both used a MAS frequency of $4 \mathrm{kHz}$, spectral width of $100 \mathrm{kHz}$, pulse delay of $0.5 \mathrm{~s}$, and a $\pi / 2$ pulse width of $4.5 \mu \mathrm{s}$. All NMR data were processed using iNMR, a commercial program by MestReC (http://www.inmr.net), and all NMR results were iteratively fit using Abscissa, a freeware app written by Rudiger Bruhl (http://rbruehl.macbay.de). For the ${ }^{13} \mathrm{C}$ MAS NMR, the time domain spectra were zero filled to a Fourier number (FN) of $32 \mathrm{k}$ points and given $5 \mathrm{~Hz}$ of exponential apodization prior to the Fourier transform (FT). For the ${ }^{133}$ Cs MAS NMR spectra, the data were zero filled to a $\mathrm{FN}$ of $64 \mathrm{k}$ points, the first three points were removed, and $200 \mathrm{~Hz}$ of exponential apodization applied before the FT. For the ${ }^{23} \mathrm{Na}$ MAS NMR spectra data were left shifted by one data point, zero filled to a FN of $32 \mathrm{k}$ points, and received $200 \mathrm{~Hz}$ of exponential apodization prior to the FT. The ${ }^{15} \mathrm{~N}$ NMR spectra used a zero fill to an FN of $16 \mathrm{k}$ points, a left shift of four data points, and $50 \mathrm{~Hz}$ of exponential apodization before the FT. In almost all cases a standard baseline correction was performed to flatten the baseline. All peak fits were performed by iteratively fitting the data set to Lorentzian lineshapes.

\section{Molecular Dynamics Simulations}

Molecular dynamics simulations were conducted in the grand canonical ensemble (GCMD) ${ }^{61}$ for $\mathrm{Na}^{+}-, \mathrm{Cs}^{+}-, \mathrm{NH}_{4}^{+}{ }_{-}^{-}$ montmorillonite. The SWy-2 model was obtained from Ngouana and Kalinichev ${ }^{48}$ and has a structural formula of $\mathrm{M}_{0.75}^{+}\left(\mathrm{Si}_{7.75} \mathrm{Al}_{0.25}\right)\left(\mathrm{Al}_{3.5} \mathrm{Mg}_{0.5}\right) \mathrm{O}_{20}(\mathrm{OH})_{4}$. The distributions of the octahedral and tetrahedral isomorphic substitutions follow a disordered pattern in accordance with Loewenstein's rule. ${ }^{63}$

The simulation supercells for all the systems consist of 32 crystallographic unit cells of montmorillonite $(4 \times 4 \times 2)$ and encompass two interlayers with surface areas of $740.2 \AA^{2}$. The large surface areas are necessary to overcome finite size effects in the simulated models. The basal spacings were varied from $9.5 \AA$ to $14.0 \AA$ at steps of $0.2 \AA$. Both interlayer galleries were constrained to have same dimensions, which were held constant throughout the simulation runs. All of the cations were initially placed at the midplane of the interlayers. The T-O-T layers were allowed to move only laterally, parallel to the basal surface, without disrupting the structure. Such translational movement is essential, because the $x$ $y$ displacement of the minimum energy interlayer structure depends on the cation and the number of intercalated fluid molecules, here $\mathrm{CO}_{2}$, as has been reported in previous studies. ${ }^{37}$

The GCMD simulations were performed with the RASPA ${ }^{62}$ simulation package. GCMD is a hybrid method which involves coupling of Monte Carlo and MD methods. In the grand canonical ensemble system temperature, system volume, and the chemical potential of the fluid molecules are fixed, but the number of adsorbed molecules fluctuates. This is achieved by sampling insertion and deletion of fluid molecules with equal probability at every MD step. The interatomic interactions for the smectite T-O-T layers and cations were obtained using the $C L A Y F F$ force field, which is used widely in clay simulations. ${ }^{48,53,64}$ The $\mathrm{CO}_{2}$ molecules were represented with the rigid EPM2 model. ${ }^{35}$ The parameters for the rigidly held $\mathrm{NH}_{4}{ }^{+}$ions were obtained from the literature. ${ }^{65}$ All the GCMD simulations were performed at $T=323 \mathrm{~K}$ and $P=90$ bars for 12 ns to reach equilibration followed by another $8 \mathrm{~ns}$ for the production run. The MD time step was $1 \mathrm{fs}$. Periodic boundary conditions in three dimensions were employed with a cutoff of $9.0 \AA$ for short range non-electrostatic interactions. Ewald summation was used for computing long-range electrostatic interactions with an accuracy of $10^{-6}$. A Nosé-Hoover thermostat were used to control the temperature. ${ }^{66}$ Fugacities required to run the simulation were obtained using the Peng-Robinson equation of state ${ }^{67}$ The critical temperature, critical pressure and acentric factor used to automatically compute the fugacity in RASPA using the equation of state. ${ }^{67}$ The computed fugacity coefficient of $\mathrm{CO}_{2}$ molecules at $323 \mathrm{~K}$ and 90 bar corresponds to 0.654 . The adsorption isotherms and related immersion energies were calculated using the data from the last $2 \mathrm{~ns}$ of the equilibrium trajectory. The reported mean values are obtained using statistical averages over 5 equal time blocks of 400 ps each. The use of immersion energies to investigate the equilibrium states of smectite systems has been discussed previously for water adsorption ${ }^{52-53}$ and is extended here to $\mathrm{CO}_{2}$.

\section{ASSOCIATED CONTENT}

Supporting Information. Methods section detailing the infrared and quartz crystal microbalance techniques; X-ray diffraction tracings of clays exposed to vacuum and pressurized $\mathrm{CO}_{2}$; electronic structure calculations of the solvation energy of the cations shown in Figure 1. This material is available free of charge via the Internet at http://pubs.acs.org.

\section{AUTHOR INFORMATION}

\section{Corresponding Authors}

HT Schaef, todd.schaef@pnnl.gov ES Ilton, eugene.ilton@pnnl.gov JS Loring, john.loring@pnnl.gov

\section{Author Contributions}

The manuscript was written through contributions of all authors. All authors have given approval to the final version of the manuscript.

\section{ACKNOWLEDGMENT}


This material is based upon work supported by the U.S. Department of Energy (DOE), Office of Science, Office of Basic Energy Sciences (BES), Chemical Sciences, Geosciences, and Biosciences Division through its Geosciences program at Pacific Northwest National Laboratory (PNNL) (JSL, ESI, KST, DAD, KMR), and through its university grants DE-FG02-10ER16128 and DEFG02-08ER15929 (GMB, NL, AOY, RJK). DAD also thanks the Robert Ramsay Fund at the University of Alabama for support. It is also based upon work supported by the DOE Office of Fossil Energy at PNNL through the National Energy Technology Laboratory, Morgantown, West Virginia (HTS, BPM). SDB and DWH collected the NMR data at the Environmental Molecular Science Laboratory (EMSL), a DOE Office of Science User Facility sponsored by the Office of Biological and Environmental Research and located at PNNL. The authors would like to thank Dr. Sebastien Kerisit for insightful comments. 


\section{REFERENCES}

(1) Kuila, U.; McCarty, D. K.; Derkowski, A.; Fischer, T. B.; Topor, T.; Prasad, M. Nano-Scale Texture and Porosity of Organic Matter and Clay Minerals in Organic-Rich Mudrocks. Fuel 2014, 135, 359-373.

(2) Kuila, U.; Prasad, M. Specific Surface Area and Pore-Size Distribution in Clays and Shales. Geophys. Prospect. 2013, $61(2), 341-362$.

(3) Ross, D. J. K.; Bustin, R. M. The Importance of Shale Composition and Pore Structure Upon Gas Storage Potential of Shale Gas Reservoirs. Mar. Pet. Geol. 2009, 26 (6), 916-927.

(4) Busch, A.; Bertier, P.; Gensterblum, Y.; Rother, G.; Spiers, C. J.; Zhang, M.; Wentinck, H. M. On Sorption and Swelling of $\mathrm{CO}_{2}$ in Clays. Geomechanics and Geophysics for Geo-Energy and Geo-Resources 2016, 2 (2), $111-130$.

(5) Josh, M.; Esteban, L.; Delle Piane, C.; Sarout, J.; Dewhurst, D. N.; Clennell, M. B. Laboratory Characterisation of Shale Properties. J. Pet. Sci. Eng. 2012, 88-89, 107-124.

(6) Gaus, I. Role and Impact of $\mathrm{CO}_{2}$-rock Interactions During $\mathrm{CO}_{2}$ Storage in Sedimentary Rocks. Int. J. Greenhouse Gas Control 2010, 4 (1), 73-89.

(7) Middleton, R. S.; Gupta, R.; Hyman, J. D.; Viswanathan, H. S. The Shale Gas Revolution: Barriers, Sustainability, and emerging Opportunities. Appl. Energy 2017, 199, 88-95.

(8) Liu, S. Y.; Yan, Z. L.; Fu, L. J.; Yang, H. M. Hierarchical Nano-Activated Silica Nanosheets for Thermal Energy Storage. Sol. Energy Mater. Sol. Cells 2017, 167, 140-149.

(9) Guo, Z. Q.; Li, Y.; Zhang, S. W.; Niu, H. H.; Chen, Z. S.; Xu, J. Z. Enhanced Sorption of Radiocobalt from Water by Bi(III) Modified Montmorillonite: A Novel Adsorbent. J. Hazard. Mater. 2011, 192 (1), 168-175.

(10) Yang, R. T.; Baksh, M. S. A. Pillared Clays as a New Class of Sorbents for Gas Separation AIChE Journal 1991, 37 (5), 679-686.

(11) De Pourcq, K.; Ayora, C.; Garcia-Gutierrez, M.; Missana, T.; Carrera, J. A Clay Permeable Reactive Barrier to Remove Cs-137 from Groundwater: Column Experiments. J. Environ. Radioact. 2015, 149, 36-42.

(12) Segad, M.; Jonsson, B.; Akesson, T.; Cabane, B. Ca/Na Montmorillonite: Structure, Forces and Swelling Properties. Langmuir 2010, 26 (8), 5782-5790.

(13) Schaef, H. T.; Ilton, E. S.; Qafoku, O.; Martin, P. F.; Felmy, A. R.; Rosso, K. M. In situ XRD Study of Ca ${ }^{2+}$ Saturated Montmorillonite (STX-1) Exposed to Anhydrous and Wet Supercritical Carbon Dioxide. Int. J. Greenhouse Gas Control 2012, 220-229.

(14) Ferrage, E.; Lanson, B.; Sakharov, B. A.; Drits, V. A. Investigation of Smectite Hydration Properties by Modeling Experimental X-ray Diffraction Patterns: Part I. Montmorillonite Hydration Properties. Am. Mineral. 2005, 90 (8-9), 13581374.

(15) Busch, A.; Alles, S.; Gensterblum, Y.; Prinz, D.; Dewhurst, D. N.; Raven, M. D.; Stanjek, H.; Krooss, B. M. Carbon Dioxide Storage Potential of Shales. Int. J. Greenhouse Gas Control 2008, 2 (3), 297-308.

(16) Sun, L. L.; Hirvi, J. T.; Schatz, T.; Kasa, S.; Pakkanen, T. A. Estimation of Montmorillonite Swelling Pressure: A Molecular Dynamics Approach. J. Phys. Chem. C 2015, 119 (34), 19863-19868.

(17) Pei, P.; Ling, K. G.; He, J.; Liu, Z. Z. Shale Gas Reservoir Treatment by a $\mathrm{CO}_{2}$-Based Technology. J. Nat. Gas Sci. Eng. 2015, 26, 1595-1606.

(18) Berend, I.; Cases, J. M.; Francois, M.; Uriot, J. P.; Michot, L.; Masion, A.; Thomas, F. Mechanism of Adsorption and Desorption of Water-Vapor by Homoionic Montmorillonites 2. The $\mathrm{Li}^{+}, \mathrm{Na}^{+}, \mathrm{K}^{+}, \mathrm{Rb}^{+}$, and $\mathrm{Cs}^{+}$-Exchanged Forms. Clays Clay Miner. 1995, 43 (3), 324-336.

(19) Cases, J. M.; Berend, I.; Besson, G.; Francois, M.; Uriot, J. P.; Thomas, F.; Poirier, J. E. Mechanism of Adsorption and Desorption of Water-Vapor by Homoionic Montmorilonite. 1. The Sodium-Exchanged Form Langmuir 1992, 8 (11), 2730-2739.

(20) Cases, J. M.; Berend, I.; Francois, M.; Uriot, J. P.; Michot, L. J.; Thomas, F. Mechanism of Adsorption and Desorption of Water vapor by Homoionic Montmorillonite .3. The $\mathrm{Mg}^{2+}, \mathrm{Ca}^{2+}, \mathrm{Sr}^{2+}$ and $\mathrm{Ba}^{2+}$ Exchanged Forms. Clays Clay Miner. 1997, 45 (1), 8-22.

(21) Whitley, H. D.; Smith, D. E. Free Energy, Energy, and Entropy of Swelling in Cs-, Na-, and Sr-Montmorillonite Clays. J. Chem. Phys. 2004, 120 (11), 5387-5395.

(22) Teich-McGoldrick, S. L.; Greathouse, J. A.; Jove-Colon, C. F.; Cygan, R. T. Swelling Properties of Montmorillonite and Beidellite Clay Minerals from Molecular Simulation: Comparison of Temperature, Interlayer Cation, and Charge Location Effects. J. Phys. Chem. C 2015, 119 (36), 20880-20891.

(23) Loring, J. S.; Schaef, H. T.; Turcu, R. V. F.; Thompson, C. J.; Miller, Q. R. S.; Martin, P. F.; Hu, J. Z.; Hoyt, D. W.; Qafoku, O.; Ilton, E. S.; Felmy, A. R.; Rosso, K. M. In Situ Molecular Spectroscopic Evidence for $\mathrm{CO}_{2}$ Intercalation into Montmorillonite in Supercritical Carbon Dioxide. Langmuir 2012, 28 (18), 7125-7128.

(24) Loring, J. S.; Schaef, H. T.; Thompson, C. J.; Turcu, R. V.; Miller, Q. R.; Chen, J.; Hu, J.; Hoyt, D. W.; Martin, P. F.;

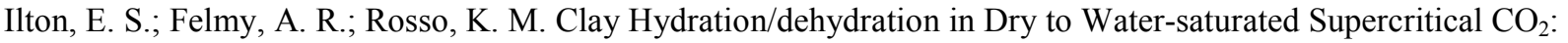
Implications for Caprock Integrity. Energy Procedia 2013, 37 (0), 5443-5448.

(25) Ilton, E. S.; Schaef, H. T.; Qafoku, O.; Rosso, K. M.; Felmy, A. R. In Situ X-ray Diffraction Study of Na+ Saturated Montmorillonite Exposed to Variably Wet Super Critical $\mathrm{CO}_{2}$. Environ. Sci. Technol. 2012, 46 (7), 4241-4248. 
(26) Loring, J. S.; Ilton, E. S.; Chen, J.; Thompson, C. J.; Martin, P. F.; Bénézeth, P.; Rosso, K. M.; Felmy, A. R.; Schaef, H. T. In Situ Study of $\mathrm{CO}_{2}$ and $\mathrm{H}_{2} \mathrm{O}$ Partitioning Between $\mathrm{Na}-$ Montmorillonite and Variably Wet Supercritical Carbon Dioxide. Langmuir 2014, 30 (21), 6120-6128.

(27) Giesting, P.; Guggenheim, S.; van Groos, A. F. K.; Busch, A. X-ray Diffraction Study of K- and Ca-Exchanged Montmorillonites in $\mathrm{CO}_{2}$ Atmospheres. Environ. Sci. Technol. 2012, 46 (10), 5623-5630.

(28) Giesting, P.; Guggenheim, S.; van Groos, A. F. K.; Busch, A. Interaction of Carbon Dioxide with Na-Exchanged Montmorillonite at Pressures to 640 Bars: Implications for $\mathrm{CO}_{2}$ Sequestration. Int. J. Greenhouse Gas Control 2012, 8, 7381.

(29) Rother, G.; Ilton, E. S.; Wallacher, D.; Hauss, T.; Schaef, H. T.; Qafoku, O.; Rosso, K. M.; Felmy, A. R.; Krukowski, E. G.; Stack, A. G.; Grimm, N.; Bodnar, R. J. $\mathrm{CO}_{2}$ Sorption to Subsingle Hydration Layer Montmorillonite Clay Studied by Excess Sorption and Neutron Diffraction Measurements. Environ. Sci. Technol. 2013, 47 (1), $205-211$.

(30) Schaef, H. T.; Loring, J. S.; Glezakou, V.-A.; Miller, Q. R. S.; Chen, J.; Owen, A. T.; Lee, M.-S.; Ilton, E. S.; Felmy, A. R.; McGrail, B. P.; Thompson, C. J. Competitive Sorption of $\mathrm{CO}_{2}$ and $\mathrm{H}_{2} \mathrm{O}$ in 2:1 Layer Phyllosilicates. Geochim. Cosmochim. Acta 2015, 161, 248-257.

(31) Kadoura, A.; Narayanan Nair, A. K.; Sun, S. Molecular Simulation Study of Montmorillonite in Contact with Variably Wet Supercritical Carbon Dioxide. J. Phys. Chem. C 2017, 121 (11), 6199-6208.

(32) Rao, Q.; Leng, Y. Molecular Understanding of $\mathrm{CO}_{2}$ and $\mathrm{H}_{2} \mathrm{O}$ in a Montmorillonite Clay Interlayer under $\mathrm{CO}_{2}$ Geological Sequestration Conditions. J. Phys. Chem. C 2016, 120 (5), 2642-2654.

(33) Sena, M. M.; Morrow, C. P.; Kirkpatrick, R. J.; Krishnan, M. Supercritical Carbon Dioxide at Smectite MineralWater Interfaces: Molecular Dynamics and Adaptive Biasing Force Investigation of $\mathrm{CO}_{2} / \mathrm{H}_{2} \mathrm{O}$ Mixtures Nanoconfined in NaMontmorillonite. Chem. Mater. 2015, 27 (20), 6946-6959.

(34) Criscenti, L. J.; Cygan, R. T. Molecular Simulations of Carbon Dioxide and Water: Cation Solvation. Environ. Sci. Technol. 2013, 47 (1), 87-94.

(35) Cygan, R. T.; Romanov, V. N.; Myshakin, E. M. Molecular Simulation of Carbon Dioxide Capture by Montmorillonite Using an Accurate and Flexible Force Field. J. Phys. Chem. C 2012, 116 (24), 13079-13091.

(36) Myshakin, E. M.; Saidi, W. A.; Romanov, V. N.; Cygan, R. T.; Jordan, K. D. Molecular Dynamics Simulations of Carbon Dioxide Intercalation in Hydrated Na-Montmorillonite. J. Phys. Chem. C 2013, 117 (21), 11028-11039.

(37) Botan, A.; Rotenberg, B.; Marry, V.; Turq, P.; Noetinger, B. t. Carbon Dioxide in Montmorillonite Clay Hydrates: Thermodynamics, Structure, and Transport from Molecular Simulation. J. Phys. Chem. C 2010, 114 (35), $14962-14969$.

(38) Zhang, W.; Hu, H.; Li, X.; Fang, Z. Interplay of Montmorillonite- $\mathrm{H}_{2} \mathrm{O}-\mathrm{ScCO}_{2}$ System Between Mechanical Behavior and Adsorption: Molecular Dynamics. J. Phys. Chem. C 2015, 119 (38), 21959-21968.

(39) Krishnan, M.; Saharay, M.; Kirkpatrick, R. J. Molecular Dynamics Modeling of $\mathrm{CO}_{2}$ and Poly(ethylene glycol) in Montmorillonite: The Structure of Clay-Polymer Composites and the Incorporation of $\mathrm{CO}_{2}$. J. Phys. Chem. C 2013, 117 (40), 20592-20609.

(40) Makaremi, M.; Jordan, K. D.; Guthrie, G. D.; Myshakin, E. M. Multiphase Monte Carlo and Molecular Dynamics Simulations of Water and $\mathrm{CO}_{2}$ Intercalation in Montmorillonite and Beidellite. J. Phys. Chem. C 2015, 119 (27), 1511215124.

(41) Myshakin, E. M.; Makaremi, M.; Romanov, V. N.; Jordan, K. D.; Guthrie, G. D. Molecular Dynamics Simulations of Turbostratic Dry and Hydrated Montmorillonite with Intercalated Carbon Dioxide. J. Phys. Chem. A 2014, 118 (35), 74547468.

(42) Lee, M.-S.; McGrail, B. P.; Glezakou, V.-A. Microstructural Response of Variably Hydrated Ca-rich Montmorillonite to Supercritical $\mathrm{CO}_{2}$. Environ. Sci. Technol. 2014, 48 (15), 8612-8619.

(43) Sidey, V. On the Effective Ionic Radii for Ammonium. Acta Crystallogr., Sect. B. Struct. Sci. 2016, 72, 626-633.

(44) Emsley, J. The Elements, 2nd ed.; Clarendon Press: Oxford, 1991

(45) Cruz-Guzmán, M.; Celis, R.; Hermosín, M. C.; Cornejo, J. Adsorption of the Herbicide Simazine by Montmorillonite Modified with Natural Organic Cations. Environ. Sci. Technol. 2004, 38 (1), 180-186.

(46) Morrow, C. P.; Yazaydin, A. O.; Krishnan, M.; Bowers, G. M.; Kalinichev, A. G.; Kirkpatrick, R. J. Structure, Energetics, and Dynamics of Smectite Clay Interlayer Hydration: Molecular Dynamics and Metadynamics Investigation of Na-Hectorite. J. Phys. Chem. C 2013, 117 (10), 5172-5187.

(47) Gautier, M.; Muller, F.; Le Forestier, L.; Beny, J. M.; Guegan, R. NH4-Smectite: Characterization, Hydration Properties and Hydro Mechanical Behaviour. Appl. Clay Sci. 2010, 49 (3), 247-254.

(48) Ngouana, B. F.; Kalinichev, A. G. Structural Arrangements of Isomorphic Substitutions in Smectites: Molecular Simulation of the Swelling Properties, Inter layer Structure, and Dynamics of Hydrated Cs-Montmorillonite Revisited with New Clay Models. J. Phys. Chem. C 2014, 118 (24), 12758-12773.

(49) Kosakowski, G.; Churakov, S. V.; Thoenen, T. Diffusion of Na and Cs in Montmorillonite. Clays Clay Miner. 2008, 56 (2), 190-206.

(50) Shannon, R. D. Revised Effective Ionic-Radii and Systematic Studies of Interatiomic Distances in Halides and Chalcogenides. Acta Crystallogr. Sect. A 1976, 32 (SEP1), 751-767.

(51) Masterton, W. L.; Bolocofsky, D.; Lee, T. P. Ionic Radii from Scaled Particle Theory of Salt Effect. J. Phys. Chem. 1971, 75 (18), 2809-2815. 
(52) Smith, D. E. Molecular Computer Simulations of the Swelling properties and Interlayer Structure of Cesium Montmorillonite. Langmuir 1998, 14 (20), 5959-5967.

(53) Loganathan, N.; Yazaydin, A. O.; Bowers, G. M.; Kalinichev, A. G.; Kirkpatrick, R. J. Structure, Energetics, and Dynamics of $\mathrm{Cs}^{+}$and $\mathrm{H}_{2} \mathrm{O}$ in Hectorite: Molecular Dynamics Simulations with an Unconstrained Substrate Surface. J. Phys. Chem. C 2016, 120 (19), 10298-10310.

(54) Vivaldi, J. L. M.; Vilchez, F. G.; Hernaiz, M.; Castro, B. d.; Gallego, M. R. The Thermal Decomposition of NH 4 Montmorillonites. Part 1. Mineralogical Society of Great Britain and Ireland 1959, 81-87.

(55) Bowers, G. M.; Schaef, H. T.; Loring, J. S.; Hoyt, D. W.; Burton, S. D.; Walter, E. D.; Kirkpatrick, R. J. Role of Cations in $\mathrm{CO}_{2}$ Adsorption, Dynamics, and Hydration in Smectite Clays under in Situ Supercritical CO $\mathrm{CO}_{2}$ Conditions. J. Phys. Chem. C 2017, 121 (1), 577-592.

(56) Bank, S.; Bank, J. F.; Ellis, P. D. Solid-State ${ }^{113}$ Cd Nuclear Magnetic-Resonance Study of Exchanged Montmorillonites. J. Phys. Chem. 1989, 93 (12), 4847-4855.

(57) Weiss, C. A.; Kirkpatrick, R. J.; Altaner, S. P. The Structural Environments of Cations Adsorbed Onto Clays ${ }^{133}$ Cs Variable Temperature MAS NMR Spectroscopic Study of Hectorite Geochim. Cosmochim. Acta 1990, 54 (6), $1655-1669$.

(58) Reinholdt, M. X.; Kirkpatrick, R. J.; Pinnavaia, T. J. Montmorillonite-poly(ethylene oxide) Nanocomposites: Interlayer Alkali Metal Behavior. J. Phys. Chem. B 2005, 109 (34), 16296-16303.

(59) Bowers, G. M.; Singer, J. W.; Bish, D. L.; Kirkpatrick, R. J. Alkali Metal and $\mathrm{H}_{2} \mathrm{O}$ Dynamics at the Smectite/Water Interface. J. Phys. Chem. C 2011, 115 (47), 23395-23407.

(60) Aranda, P.; Ruizhitzky, E. Poly(Ethylene Oxide)-Silicate Intercalation materials Chem. Mater. 1992, 4 (6), 13951403.

(61) Boinepalli, S.; Attard, P. Grand Canonical Molecular Dynamics. J. Chem. Phys. 2003, 119 (24), 12769-12775.

(62) Dubbeldam, D.; Calero, S.; Ellis, D. E.; Snurr, R. Q. RASPA: Molecular Simulation Software for Adsorption and Diffusion in Flexible Nanoporous Materials. Mol. Simul. 2016, 42 (2), 81-101.

(63) Loewenstein, W. The Distribution of Aluminum in the Tetrahedra of Silicates and Aluminates. Am. Mineral. 1954, 39 $(1-2), 92-96$.

(64) Cygan, R. T.; Liang, J. J.; Kalinichev, A. G. Molecular Models of Hydroxide, Oxyhydroxide, and Clay Phases and the Development of a General Force Field. J. Phys. Chem. B 2004, 108 (4), 1255-1266.

(65) Loganathan, N.; Kalinichev, A. G. On the Hydrogen Bonding Structure at the Aqueous Interface of AmmoniumSubstituted Mica: A Molecular Dynamics Simulation. Zeitschrift Fur Naturforschung Section a-a Journal of Physical Sciences 2013, 68 (1-2), 91-100.

(66) Shinoda, W.; Shiga, M.; Mikami, M. Rapid Estimation of Elastic Constants by Molecular Dynamics Simulation Under Constant Stress. Phys. Rev. B 2004, 69 (13).

(67) Peng, D.; Robinson, D. B. New 2-constant Equeation of State Ind. Eng. Chem. Fundam. 1976, 15 (1), $59-64$. 
TOC
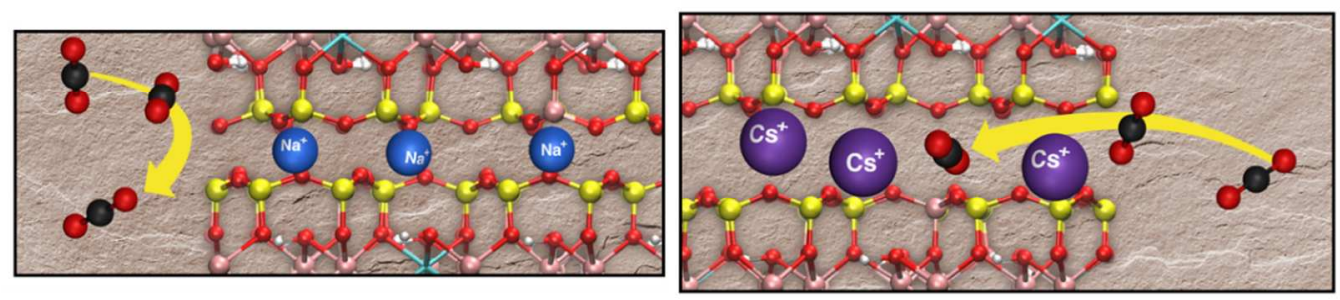